Hispania Sacra, LXII

126, julio-diciembre 2010, 697-721, ISSN: 0018-215-X

\title{
EL MONASTERIO DE SAN JOSÉ: POBLACIÓN CONVENTUAL Y VINCULACIONES SOCIALES DEL CARMELO DESCALZO EN EL TUCUMÁN (1790-1806)
}

POR

\author{
Ana Mónica GonZÁlez FASANI \\ Universidad Nacional del Sur, Bahía Blanca
}

\begin{abstract}
RESUMEN
El 7 de mayo de 1628 nacía en la ciudad de Córdoba del Tucumán el monasterio carmelita de San José. Su patrono y fundador, Juan de Tejeda, perteneciente a una de las familias más distinguidas de la sociedad cordobesa, lo dotó con bienes materiales e ingresaron en èl sus dos hijas. A finales del siglo XVIII dentro del monasterio se vivía con la austeridad y la piedad que lo vio nacer. Las vocaciones se sucedían sin mengua y, la estela de Trento seguía marcando el rumbo.

PALABRAS ClAVE: Córdoba, siglo XVIII, monjas, vocaciones, visitas episcopales, patrimonio.

\section{THE MONASTERY OF SAN JOSE: POPULATION AND SOCIAL LINKS CONVENTUAL THE DISCALCED CARMELITE ORDER IN TUCUMAN (1790-1806)}

\begin{abstract}
On May 7, 1628 was born in the city of Cordoba on Tucuman the Carmelite monastery of St. Joseph. Its founder and patron, Juan Tejeda, belonging to one of the most distinguished families in society Cordoba, endowed with money, slaves, lands and their two daughters. In the late eighteenth century were living inside the monastery with the austerity and piety that it was born. Vocations successive without decrease and the wake of Trento still marking the course.
\end{abstract}

KEY WORDS: Córdoba, XVIII century, nuns, vocations, episcopal visits, patrimony.

Recibido/Received 19-06-2008

Aceptado/Accepted 11-12-2009 
A comienzos del siglo XVII las fundaciones de monasterios carmelitas descalzos habían traspasado largamente las fronteras de la ciudad natal de Teresa de Jesús, extendiéndose por España e incluso por las Indias. ${ }^{1}$ Llegaron al Virreinato de Nueva España en 1604 y dos décadas después se arraigaron en el Tucumán.

El 7 de mayo de 1628 en Córdoba del Tucumán nacía el monasterio de San José, cuando la ciudad estaba aún poco desarrollada y se contaban ya catorce años de la creación del primer monasterio femenino de clausura, el dominico de Santa Catalina de Sena. A partir de ese momento y hasta la actualidad, el espíritu teresiano se adueñó de las celdas y los claustros del monasterio cordobés.2 La descalcez, es decir, la reforma, personificada en Santa Teresa y sus seguidoras, buscaba una vida de mayor compromiso frente a los votos que toda religiosa de su tiempo profesaba: pobreza, castidad, obediencia y permanencia en la clausura. ${ }^{3}$

La fundación en Córdoba fue fruto de la devoción de don Juan de Tejeda Miraval, vecino feudatario de la ciudad, ${ }^{4}$ perteneciente a una de las familias más encumbradas de la sociedad cordobesa. En el actual territorio argentino, fueron casi inexistentes los títulos nobiliarios y de excepción, los vínculos de mayorazgo y los hábitos de las órdenes militares. Por tal razón, los actos positivos que caracterizaban a los hidalgos criollos diferían en la práctica de los de la Península. La sangre heredada, los méritos militares, los estudios superiores, los hábitos sacerdotales, los cargos políticos, el matrimonio, los bienes raíces y la fortuna, han obrado como elementos condicionantes de la pertenencia a la clase patricia. Para el caso de Córdoba pueden distinguirse ocho categorías: sangre, espada, toga, hábito, cargo, alianza, tierra y bolsillo. En el caso de la familia Tejeda, a la hidalguía, se sumaron las otras. ${ }^{5}$

El apellido Tejeda Miraval está fuertemente asociado a la conquista del territorio y fundación de ciudades. Don Juan de Tejeda fue uno de los siete hijos del matrimonio contraído entre Tristán de Tejeda y doña Leonor Mejía y Miraval. Tristán de Tejeda había nacido en Deza y era sobrino nieto de Santa Teresa de Jesús. Acompañó a Jerónimo Luis de Cabrera al Tucumán y participó de las expediciones de conquista y en la fundación de Córdoba como así también al des-

\footnotetext{
${ }^{1}$ Hoy es bien conocido el apoyo que encontraron en la Corte los sostenedores del carmelo descalzo. Cordura VAN WYHe, «Piety and Politics in the Royal Convent of Discalced Carmelite nuns in Brussels 1607-1646», Revue d'Histoire Ecclésiastique de Belgique, 1001 (2005) 457-487.

${ }^{2}$ Esta apreciación parte de mis conversaciones en el locutorio del monasterio con la madre Teresa, actual priora del monasterio.

${ }^{3}$ Isabelle PoutRIN, «Las mujeres en el siglo de las reformas», Antonio Luis CoRTÉs PeÑA, (coord.), Historia del Cristianismo, III, Madrid, 2006, 522-527.

${ }^{4}$ Arturo G. LazCano Colodrero, Cabildantes de Córdoba, Córdoba, 1944, 192.

${ }^{5}$ Prudencio Bustos ArgaÑaraz, «El Patriciado de Córdoba. Contribución al estudio de su génesis», Boletín del Centro de Estudios Genealógicos de Córdoba, 27 (1998) 15-17.
} 
cubrimiento del Río de la Plata. Si bien su actuación militar fue muy exitosa, también lo fue la civil dado que ocupó en Córdoba todos los cargos que significaban funciones públicas en esa época: regidor, contador y tesorero de la Real Hacienda, alcalde ordinario de primer voto, alférez real, procurador general. En premio a sus servicios obtuvo algunas encomiendas, siendo propietario de la estancia de Soto, de gran importancia por sus trabajos textiles y la producción de vinos de primera calidad. ${ }^{6}$

En el presente trabajo se intentará reconstruir la vida en la clausura conventual, mostrando a partir del análisis de las profesiones ocurridas durante un lapso de veintiséis años (1780-1806), la procedencia y el círculo familiar de pertenencia de cada una de las profesas. Tomando como base la detallada visita realizada por el obispo Ángel Mariano Moscoso, recrearemos las prácticas de este grupo de veintiún mujeres consagradas y el modo en que llevaron sus finanzas en un momento en que las reformas borbónicas y el aumento del control episcopal se dejan sentir en la Córdoba tardocolonial.

\section{NACE El CARMelo}

Don Juan de Tejeda y Miraval nació dos años después de fundada la ciudad de Córdoba, en 1575, y fue, en virtud de sus méritos y servicios encomendero de Nono, Pichana y Añáscate. Ocupó en repetidas ocasiones los principales cargos públicos: alcalde de primer voto en 1609; regidor en 1610; procurador general en 1613 y 1622; alcalde ordinario de primer voto entre los años 16141617 y 1620, año en que se lo elige alférez real. En 1621 es reelegido alcalde ordinario de primer voto. Don Juan había contraído nupcias con Ana María de Guzmán, hija de don Pablo de Guzmán ${ }^{7}$ y de este matrimonio nacieron cinco hijos, tres varones y dos mujeres: Luis José de Tejeda; Gregorio de Tejeda; Gabriel de Tejeda; María Magdalena de Tejeda y Alejandra de Guzmán.

El nombre de los Tejeda está asociado en la historia de Córdoba por un lado con el establecimiento mismo de la ciudad y, por otro, con las fundaciones pia-

\footnotetext{
${ }^{6}$ En el reparto de solares le correspondió la cuarta manzana. Falleció anciano a los 85 años en agosto de 1617. Ibidem 191. Doña Leonor Mejía y Miraval, su madre, era hija del conquistador don Hernando Mejía Miraval y de doña María Mancho, india principal.

${ }^{7}$ General; caballero hidalgo. Descendiente de la casa de los duques de Medina Sidonia. Hijo de don Luis de Guzmán, gobernador de la provincia de Popayán, en Tierra Firme. Ocupó cargos públicos en la ciudad de Córdoba como alcalde ordinario de primer voto, procurador general, regidor. Se casó en Lima con María Magdalena de la Vega y tuvieron una sola hija, Ana María. Tenía un primo -Martín Miguel de Guzmán- casado con María de Cepeda y Ahumada, hermana de la mística castellana quien había tenido la dicha de conocerla. Ibidem 86 y Ana María MARTíneZ DE SÁncheZ, La cofradía del Carmen en la Iglesia de Santa Teresa de Córdoba, Córdoba, 2000, 23.
} 
dosas. ${ }^{8}$ Generosidad, humildad y pobreza eran los valores exaltados por los hombres ilustres en la segunda mitad del siglo XVI y en la primera del XVII. Para vivir en consonancia con estas meritorias convicciones, don Juan se propuso, según consta en la escritura de fundación del monasterio de San José9 la fundación de un hospital bajo la misma advocación e invitar a los hermanos hospitalarios de San Juan de Dios a administrarlo. Las tratativas se habían puesto en marcha alrededor del año 1619 pero no cuajaron. Poco tiempo después, en julio de 1622, en un viaje con su familia al obraje de Soto para pagar a sus indios lo que les debía, enfermó gravemente su hija María Magdalena, «la más querida». Así lo relata don Juan de Tejeda:

Sucedió que estando yo en mi obraje de Soto, veinticinco leguas de esta ciudad con toda mi casa, mujer, hijos, suegra y demás familia por el mes de julio pasado [...] de seiscientos y veinte y dos, fue Dios servido de llegar a tal extremo de una muy grave enfermedad a una de dos hijas que tengo llamada Maria de Tejeda, y no bastando remedios humanos para recobrarla, [...] fue servido de darme la ofrecí a la bienaventurada Santa Teresa de Jesús por monja de su Santa Religión, y fundarla un monasterio del patrimonio de la dicha mi hija y de parte de mi hacienda, si alcanzaba con su intercesión que nuestro Señor concediese salud y vida a la dicha mi hija, y poniéndole sobre el lado del corazón casi difunto una lámina pequeña de una imagen de la bienaventurada Santa Teresa de Jesús, fue caso milagroso que luego al punto volvió en sí la dicha mi hija, [...] y desde aquel punto fue conocida su mejoría.

A partir de ese momento Tejeda puso todo su empeño en cumplir su promesa. Había que revocar la donación anterior, hecha a favor de la Orden de San Juan de Dios, traspasar los bienes a esta nueva fundación y recibir el permiso real para levantar un monasterio en las casas destinadas para su morada. Estos trámites podían demorarse muchos años, como sucedió en otras fundaciones en América. Sin embargo, en poco más de cinco se abrieron las puertas del nuevo cenobio. ${ }^{10}$

\footnotetext{
${ }^{8}$ Se debe a doña Leonor de Tejeda, hermana de don Juan, la fundación del monasterio de Santa Catalina de Sena unos años antes. Roberto LeVILLIER (dir.), Papeles eclesiásticos del Tucumán. Documentos originales del Archivo de Indias, II, Madrid, 1926, 403-414.

${ }^{9}$ Archivo del Arzobispado de Córdoba (en adelante AAC), Escritura de fundación del monasterio de Santa Teresa, Leg. 59, T. I, Historia del Monasterio de Santa Teresa.

${ }^{10}$ Durante el reinado de Felipe II, los conventos carmelitas se expandieron dentro y fuera de España y se convirtieron en la expresión de la idea de «aula sacra» sostenida por los Austrias. Al promocionar la corte como un lugar semisagrado, la corona fortaleció su pretensión a la autoridad divina. A su vez, el rey Felipe III, custodio de la catolicidad de su imperio, amparó y respaldó la fundación de monasterios descalzos reformados. Enrique Martínez Ruiz, El peso de la Iglesia. Cuatro siglos de órdenes religiosas en España, Madrid, 2004, 125 y ss. J. Martínez Millán y M. A. Visceglia (dirs.), La monarquía de Felipe III: La Casa del Rey, I, Madrid, 2008, 187-197.
}

Hispania Sacra, LXII

126, julio-diciembre 2010, 697-721, ISSN: 0018-215-X 
Así, la fundación del monasterio de Carmelitas fue promovida por una imagen de santa Teresa traída por don Pablo de Guzmán, suegro de don Juan y un hecho milagroso vinculado a ella. ${ }^{11}$

A don Juan de Tejeda se le recuerda como un hombre piadoso e igualmente emprendedor, hábil y diligente en el manejo de sus bienes. Dueño de un obraje en Soto participó del comercio de los textiles, mulas y vino con el Alto Perú. Con un derecho eminente sobre sus bienes, y contando con el consentimiento de su esposa y de sus suegros, quienes habían otorgado todos sus bienes en legítima herencia, los puso a disposición de la nueva fundación. Allí ingresaron las hijas de don Juan como fundadoras y primeras prioras. ${ }^{12}$ Pocos meses después, al quedar viuda, doña Ana María decidió consagrar su vida a la religión, y el mismo camino siguieron tres de sus nietas. Además, su hermana, Leonor de Tejeda, priora del monasterio dominico con el nombre de Catalina de Sena, se trasladó al monasterio carmelita para iniciar a las monjas en la vida religiosa.

Para evitar la precariedad y para que el monasterio pudiera cumplir los fines para los cuales fue creado, el fundador y patrono lo dotó con cuantiosos beneficios, que incluían doce mil pesos y los inmuebles donde iba a instalarse la comunidad. Junto a ello entregó doce esclavos: Francisco y Juliana su mujer y 3 hijos, Luis de 5 años, Sebastián de 6 años y Juan de 7. Antonio, casado con Lucrecia; Francisco, casado con negra de Juan de Tejeda; Pedro, soltero; Lucía con su hijo Roque de un mes y Francisco, casado con negra del licenciado Luis del Pesso.

A fin de que el monasterio funcionase con la comodidad necesaria, edificó un templo con su retablo de madera y peana de marfil puesta dentro del sagrario, de un costo de más de dos mil pesos. También hizo donación de una imagen de bulto de Santa Teresa y otros utensilios y adornos para la Iglesia, como unos tafetanes, una casulla, un frontal, dalmáticas y capa, láminas y una cruz de reliquias «que ella sola había costado 100 pesos». En cuanto a las propiedades rurales, declaró que tenía comprada una estancia, ganado y doce esclavos a cinco leguas de la ciudad en unos seis mil pesos, las que pone en manos de la Priora del monasterio o del mayordomo. En resumen, un patrimonio de 30.000 pesos.

${ }^{11}$ El milagro ocurrido en Córdoba del Tucumán por la recientemente elevada a santa, Teresa de Ahumada, fue predicado en varias ocasiones en la Península. En un momento en que el patronazgo nacional del apóstol Santiago y de la religiosa de Ávila estaba en disputa, los hechos milagrosos de ambos santos podían ayudarlos a inclinar la balanza a su favor. Recordemos que santa Teresa fue designada en 1627 para patrona de España por el papa Urbano VIII. En 1626 las Cortes de Castilla la nombraron copatrona de los Reinos de España pero los partidarios de Santiago Apóstol lograron revocar el acuerdo. Sobre este tema véase entre otros R. P. Jean-Robert ARMOGATHE, «Santiago, Patrón de las Españas?, École Pratique del Hautes Etudes, París, Instituto Bossuet.

${ }^{12} \mathrm{AAC}$, Escritura de fundación del monasterio de ... 
Debemos entender que la marcha de un monasterio dependía de que se contara con un sostén económico seguro y constante. Los gastos eran muchos: el mantenimiento del inmueble, la alimentación de las religiosas, los pagos al capellán, al mayordomo, al médico, cirujano o al barbero que las atendiera, entre otros, además de los estipendios propios del culto. También debía tener un capital suficiente para hacer frente a los pleitos o litigios que pudieran sucederse. ${ }^{13}$

En Córdoba obedecieron los preceptos de la orden, a pesar de los numerosos pedidos de ingreso, y no permitieron una comunidad grande. El grupo debía ser pequeño, no más de 21 como establecían la Regla. En el nuevo convento de Ávila, Santa Teresa había impuesto el número de trece, en recuerdo de Jesucristo y sus apóstoles. Más tarde fue cambiando a quince; posteriormente hasta veinte. De esta manera sería más exacto el seguimiento del espíritu de reforma. Unas a otras, las monjas se apoyarían, y también se vigilarían. Una comunidad pequeña tenía menos necesidades de comida y vestido que una más grande pero los gastos para mantener el inmueble o los sueldos de capellanes, médicos, y demás, eran los mismos. En cambio, los ingresos percibidos por las dotes, piso y ajuares eran más reducidos. Ahora bien, ¿cuál era la situación del monasterio de San José a finales del siglo XVIII?

\section{LAS MONJAS}

La estratégica ubicación geográfica de Córdoba del Tucumán, en el centro de una extensa región, favorecía el desplazamiento desde -y hacia ella- de hombres y mercancías en la articulación de los principales caminos existentes, por el norte hacia el Alto Perú, por el Oeste hacia Chile y por el este hacia Buenos Aires. ${ }^{14}$

Desde el punto de vista político-administrativo, hasta la implementación de las reformas borbónicas, Córdoba integró la jurisdicción del Virreinato del Perú y dentro de éste formaba parte de la Gobernación del Tucumán. Después de la creación del Virreinato del Río de la Plata en 1776, siguió dependiendo políticamente del gobernador del Tucumán y judicialmente de la Audiencia de Charcas. Con el establecimiento del régimen de Intendencias en 1782, se transformó

${ }^{13}$ Hemos consultado un expediente muy extenso, 107 fojas, sobre un pleito que el monasterio de San José mantuvo durante más de dos años, 1733-1735, con don Miguel Sopeña y don Pedro de Herrera y Velasco por la compra que hizo el síndico procurador de unas casas que fueran de los padres de Pedro de Herrera. Los casi tres años acudiendo a la justicia, notificando, esperando de ella decretos y proveimientos, fueron muy onerosos para ambas partes. En cuanto a los litigios que enfrentó el monasterio, por lo general, estaban relacionados con cuestiones inmobiliarias como poderes para vender un edificio, falta de escrituras, compra y venta de casas, falta de pagos, etc.

14 Vilma Miletich, «El Río de la Plata en la economía colonial», E. TANDETER (dir.), Nueva Historia Argentina, Buenos Aires, 2000, 210 y ss.

Hispania Sacra, LXII

126, julio-diciembre 2010, 697-721, ISSN: 0018-215-X 
en capital de la Intendencia de Córdoba del Tucumán, de la que dependían las ciudades de La Rioja, San Luis, San Juan y Mendoza. En materia eclesiástica comprendía la jurisdicción del Obispado del Tucumán. ${ }^{15}$

En la Memoria que el Marqués de Sobremonte dejó escrita para su sucesor, antes de abandonar el gobierno de la Intendencia, le decía, hablando de la capital: «Consta la ciudad de diez cuadras de Oriente a Poniente y siete de Norte a Sur, de ciento cuarenta y seis varas y dos tercios cada una, y las calles tienen once varas y dos tercias; esta es su planta o traza según el documento de fundación que se halla en el archivo del Cabildo». ${ }^{16}$ En ese espacio se movía una población heterogénea compuesta por españoles, criollos, estudiantes universitarios y colegiales del Seminario y Monserrat, indios, negros y mestizos.

Considerando ciudad y campaña, la población de Córdoba reunía, según el censo de 1778, la cantidad de 43.511 habitantes. El 83.1\% vivía en el campo y un $16.8 \%$ lo hacía en la ciudad, la cual contaba en ese año con 7.320 pobladores. La ciudad concentraba proporcionalmente el mayor número de residentes. ${ }^{17}$ Sobremonte, en la citada Memoria, anotaba: «Los padrones de la ciudad van del ingreso de mi Gobierno, de 1785, y es considerable la diferencia que hay de entonces acá: en el año próximo pasado [1796] se hicieron por el Gobierno Eclesiástico, y aunque no me parecen exactos ni he podido conseguir una bien formal noticia, juzgo que son los habitantes de la ciudad y sus orillas dependientes del curato de ella, de siete mil y quinientos a ocho mil, poco más o menos». ${ }^{18} \mathrm{La}$ esperanza de vida de esa población era de 32 años y, en cuanto a la distribución de los sexos, un $45.2 \%$ eran varones y un 54.7\%, mujeres. De entre todas ellas, 21 doncellas vírgenes permanecían perpetuamente dentro de los muros del monasterio de San José.

En una época tan tardía como el siglo XVIII, aún se registraron novedades tanto en la Península como en el Tucumán. ${ }^{19}$ En Córdoba, en el Carmelo Des-

${ }^{15}$ Hugo BECK, «Distribución territorial de la conquista. Red de urbanización y vías de comunicación», Academia Nacional de la Historia, Nueva Historia de la Nación Argentina, 2, Buenos Aires, 1999, 21-45. El obispado había sido creado en 1570, como diócesis sufragánea de la arquidiócesis de Charcas.

16 Ángel Clavero, Sch. P., Fray José Antonio de San Alberto. Obispo de Córdoba, Córdoba, 1944, 2.

${ }^{17}$ Desde el punto de vista de su composición social, había un $46.2 \%$ de blancos, frente a un $53.8 \%$ de castas distribuidas en $29.4 \%$ de libres, $13 \%$ de esclavos y $11.4 \%$ de indios. Como en la provincia, era el sector de castas el que predominaba n la sociedad cordobesa, como resultado de la intensificación del fenómeno de mestizaje. En la ciudad las castas se agrupaban en las siguientes proporciones: $29.5 \%$ de esclavos, 32.9 de pardos libres y sólo $1.3 \%$ de indios. Dora Celton, La población de la provincia de Córdoba a fines del siglo XVIII. Buenos Aires, 1993, 53.

${ }^{18}$ Ignacio Garzón, Crónica de Córdoba, Córdoba, 1901, 360.

${ }^{19}$ Apertura del monasterio cisterciense de La Trapa, con la fundación del monasterio de Santa Susana; propagación de las salesas apoyadas por la reina Bárbara de Braganza; renacimiento de los carmelitas calzados y pocos sobresaltos para los descalzos. E. MARTínez Ruiz, El peso de la Iglesia ... 179. 
calzo a diferencia de otras regiones centrales del Imperio Hispánico, nunca faltaron vocaciones. De hecho, las jóvenes debían esperar con paciencia que se produjeran vacantes para poder ingresar en el cenobio femenino.

Entre 1780 y 1806 en el convento de San José de Córdoba del Tucumán, se recibieron un número de dieciséis profesiones, entre ellas siete monjas de velo negro y tres de velo blanco. De las seis restantes no se consignan más datos que el nombre, filiación, procedencia, edad y voluntad de ingreso. Las edades en que realizaron sus profesiones van desde los diecinueve años hasta los cuarenta y siete, como fue el caso de Manuela Jacinta de Isasi, ${ }^{20}$ admitida para profesar como religiosa de velo negro en reemplazo de la fallecida madre Francisca Antonia del Corazón de Jesús. La media de edad de las profesiones se encontraba entre los 22 y los 28 años. ${ }^{21}$

El monasterio de San José fue una parte significativa de las redes sociales de la ciudad de Córdoba. Podemos darnos cuenta, por los archivos y listas de profesiones, que las carmelitas de velo negro pertenecían a las familias distinguidas y de cierta fortuna. Lo demuestran sus apellidos y el pago de la dote. Ingresaban después de un examen en el que se probaba tanto su limpieza de sangre como su legitimidad -ser hijas de cristianos casados-, su vocación para la Orden del Carmen y su disposición a una vida contemplativa.

De las dieciséis religiosas examinadas para ingresar, en los diecisiete años que abarca este estudio, siete fueron originarias de la ciudad de Córdoba, ocho habían nacido en jurisdicción del Obispado de Tucumán y sólo una era natural de Buenos Aires. La procedencia de esas mujeres revela el surgimiento de poblaciones más o menos cercanas a la ciudad capital, que nacieron como fruto de una política de expansión territorial y de un proceso de crecimiento del mundo rural. ${ }^{22}$ Procedentes de Río Tercero, se encontraba las hermanas María Mercedes Pereira y Josefa Calderón; de Río Segundo, María Luisa Álvarez y María Manuela del Rosario Quiñones. De Santa Rosa de Lima, población sobre el Río Primero, venía Teresa Fernández. De más lejos llegaron María Bernardo Doncel, procedente de Santiago del Estero; Juana Josefa Correas, natural de Mendoza, y Gregoria de los Dolores, vecina de Jujuy.

${ }^{20}$ Manuela Jacinta de Isasi -después Manuela de Jesús, María y José- era hija de Juan Bautista Isasi y Juana Luisa Echenique y Villafañe. Juan Bautista Isasi se convirtió por matrimonio en yerno de José Gregorio de Echenique y Cabrera y de Margarita Villafañe. La familia Echenique monopolizaba las varas concejiles en esa época.

${ }^{21}$ El 29 julio 1805 fue explorada la voluntad de María Manuela del Rosario Quiñones, de 34 años, natural del partido de Río Tercero Arriba. Lo particular de esta profesión lo origina el hecho de que antes de entrar al monasterio había vivido en el Colegio de Huérfanas de la ciudad fundado en 1782 por el Obispo José A. de San Alberto.

22 Dora Celton, Ciudad y campaña en la Córdoba Colonial, Córdoba, 1996, 72-113.

Hispania Sacra, LXII

126, julio-diciembre 2010, 697-721, ISSN: 0018-215-X 
Entre las jóvenes pertenecientes a los grupos dominantes de la sociedad cordobesa que decidieron a fines del siglo XVIII dejar el mundo y dedicarse a la vida contemplativa podemos mencionar también a María Luisa Cabrera de 23 años, natural de Córdoba e hija de don Nicolás Cabrera y de Doña Tomasa Allende..$^{23}$ Era una de las hermanas de José Antonio Cabrera y Allende, sobrina del Caballero de Carlos III, don Pedro Lucas de Allende; prima de la mujer de Antonio de la Bárcena y por ende, tía segunda del coronel Manuel Bárcena.

Otra de las novicias fue María del Rosario de San Francisco, quien «habiendo cumplido los 10 meses del año de probación fue admitida a los últimos votos según lo previenen nuestras constituciones y resultó aprobada para monja de velo negro en la vacante que quedó por muerte de la hermana Micaela del Espíritu Santo». María del Rosario Elía, que así se llamaba la joven, era natural de Buenos Aires, hija legítima de don Juan Ignacio Elía y doña Bárbara García, vecinos en aquella ciudad. Su padre, capitán de milicias provinciales, había ocupado el cargo de segundo regidor en el año 1781 y, por vía de matrimonio, había emparentado con la elite capitular. No sabemos por qué razón María prefiere alejarse de su entorno -siendo que la ciudad contaba con dos monasterios, uno de capuchinas y otro de dominicas ${ }^{24}$ y abrazar la regla del Carmen «sin mitigación hasta la muerte». Debemos, entonces, aceptar sus propias palabras de que no la mueve «motivo alguno temporal o terreno sino sólo por servir mejor a Dios, Nuestro Señor y asegurar la eterna salvación». ${ }^{25}$

De la ciudad de Jujuy, en 1799, llegó Gregoria de los Dolores, en el siglo María Gregoria de Arismendi, quien fue admitida como monja de velo negro en la plaza vacante por la muerte de la madre María Teresa de Jesús. Sus padres don Juan Bautista Arismendi y doña María Manuela Iturbe formaban parte de los vascos que se destacaron en la sociedad jujeña. ${ }^{26}$

$\mathrm{Al}$ año siguiente hizo su ingreso en el monasterio, como monja de velo negro, María Josefa de la Torre y Mujica, natural de Córdoba. Se trataba de la hija de don

${ }^{23}$ María Luisa Cabrera, era hermana de José Antonio Cabrera y Allende, sobrina del Caballero de Carlos III don Pedro Lucas de Allende, prima hermana de la mujer de Antonio de la Bárcena y por ende tía segunda del coronel Manuel Bárcena. Cabrera y Allende son de los apellidos más notables de la sociedad. Félix Cabrera Célis de Burgos era hijo de Félix Cabrera de Cortés y de Isabel de Zevallos y Suárez de Velazco, hija del comerciante avecindado en Buenos Aires, Juan Antonio de Zevallos. Era padre de Nicolás Cabrera casado con María Tomasa de Allende. María Tomasa era hija del General Tomás de Allende y Losa y de Bernardina Vicentelo de la Rosa y Carranza. Félix Cabrera. Eduardo SAGUIER, Genealogía de la Tragedia argentina, II Derrumbe del orden imperial absolutista y crisis del estado colonial (Río de la Plata, siglo XVIII), 2007.www.er_saguier.org.

24 Alicia FraschinA, «Despreciando al mundo y sus vanidades. Los conventos de monjas en el Buenos Aires colonial», Cuadernos de Historia Regional, Luján (2000) 71-101.

${ }^{25}$ AAC. Legajo 8. Tomo I, Monjas Teresas. Teresa Antonia de Jesús, priora.

${ }^{26}$ Gustavo PAZ, «Familia, linaje y red de parientes: la élite de Jujuy en el siglo XVIII», Andes. Antropología e Historia, 8 (1997) 145-147. 
Javier de la Torre y doña Teodora Vera. Don Javier de la Torre, era coronel del regimiento de caballería del Río Seco. Estaba casado con María Teodora de Vera y Mujica, una familia perteneciente a los notables de la ciudad de Santa Fe. De entre sus varios hijos, mencionamos a Joaquín de la Torre y Vera, casado con Teresa de Allende y Torres, hija del caballero de Carlos III, don Pedro Lucas de Allende.

Y ya en el siglo XIX, en 1806, hizo su entrada en religión la mencionada Manuela Jacinta de Isasi, hija de Juan Bautista Isasi y Juana Luisa Echenique y Villafañe.

La excepción que confirma la regla la encontramos en el caso de Margarita Magarzo de León. Esta joven era hija legítima de don Lorenzo Magarzo de León, ya fallecido, y de doña Petrona Álvarez, vecina de la ciudad. En 1792 escribió al obispo para comunicarle que hacía más de ocho años que «sentía vivamente el llamado al estado de religiosa de velo negro del convento de Santa Teresa de Jesús y por cuanto la notoria pobreza de sus padres no le puede sufragar con lo que es necesario para el dote y demás cosas preciosas para verificar sus piadosos deseos», solicitaba, por lo tanto, autorización para pedir limosna en la ciudad y su jurisdicción. El obispo destinó al Padre Superior, fray Pedro Pacheco, franciscano, para que la acompañara. A fin de año aún no había logrado su cometido «por cuanto los atrasos de esta ciudad no le han permitido colectar todo lo que necesita» y solicita permiso para extender la licencia a todo el obispado. ${ }^{27} \mathrm{Al}$ acabar 1792 sabemos que Margarita se encontraba en Jujuy, pero no volvemos a tener noticia de ella hasta cuatro años después cuando Bernabé Gregorio de las Heras, vecino de la ciudad y albacea de don José Antonio Terán, confirmó tener en su poder la cantidad de seiscientos pesos en moneda corriente que Terán dejó en cláusula testamentaria para ayuda de la dote. Al año siguiente su madre menciona la donación de trescientos pesos por parte «de un caballero de Buenos Aires y otros muchos que dijo que no tenía presente...». Cuando se produjere una vacante, sin duda Margarita podría concretar la vocación a la que había sido llamada.

\section{VISITAS Y PRÁCTICAS OBSERVANTES}

Durante el siglo XVIII el monasterio de San José recibió a sucesivos visitadores episcopales. Las visitas periódicas de superiores a los claustros de regulares y de monjas son especialmente encomendadas por el Concilio de Trento (1545-1563); en el marco de la reglamentación centrada en la reforma de la vida religiosa, en el restablecimiento y conservación de «la antigua y regular disciplina», son un instrumento para asegurar su observancia. ${ }^{28}$ Vemos, sin em-

${ }^{27}$ AAC. Legajo 8. Tomo I, Monjas Teresas. Córdoba, julio 6 de 1792.

28 Victoria Cohen Imach, «Decir verdad. Pesquisa secreta en un convento femenino del siglo XVIII», Acta Literaria, 18 (2003) 19-32.

Hispania Sacra, LXII

126, julio-diciembre 2010, 697-721, ISSN: 0018-215-X 
bargo, que, en consonancia con la política de control cada vez más férrea ejercida por la Corona a partir de la segunda mitad del siglo, las visitas se intensificaron y adquirieron un carácter más riguroso.

Las reformas borbónicas, como un programa estatal, se empeñaron en restringir el gobierno de las abadesas para consolidar su presencia y controlar la dinámica interna de los monasterios, lo que intentó ejecutar a través de los obispos, quienes se convirtieron en la época en los principales aliados políticos de las autoridades borbónicas.

Los principales aspectos de la vida cotidiana de las habitantes monacales fueron una preocupación estatal que se plasmaron en las diferentes visitas y en los autos de reforma a partir de ellas. Vale aclarar que estos cuidados no eran temas nuevos y ya se habían hecho presentes en tiempos anteriores.

La visita que abrió el siglo fue la del Obispo Manuel Mercadillo, ${ }^{29}$ quien instó a la comunidad a guardar cuidadosamente el silencio y a vigilar mejor las puertas. ${ }^{30}$ Entre 1726 y 1730 ocupó la sede episcopal el doctor don Juan de Sarricolea y Olea quien expresó que: «Las carmelitas compiten con ellas [las catalinas] en perfección de espíritu, emulando ambos (conventos) para sí los mejores carismas de la gracia, a que aspiran fervorosos con el más estrecho cumplimiento de sus reglas». ${ }^{31}$ Este juicio desconcierta si tenemos en cuenta las graves faltas que encontró pocos años después, en el convento de las teresas el obispo José Antonio Gutiérrez de Zevallos, cuando realizaba su visita a los conventos de su diócesis. Gracias al carácter que tomó esta visita que derivó en un recurso a la Audiencia de Charcas e incluso al mismo Rey, ${ }^{32}$ la documentación que se encuentra sobre ella es muy abundante, si la comparamos con otras de las que sólo han quedado escasas menciones. ${ }^{33}$

\footnotetext{
${ }^{29}$ Fray Manuel Mercadillo, dominico, fue el noveno y último obispo de la etapa de los obispos residentes en Santiago del Estero. Ocupó la sede entre los años 1699 y 1704. A él se debe el traslado de la sede episcopal a la ciudad de Córdoba pues fue su promotor antes de haber venido a estas tierras, lo que concretó por Real Cédula de Carlos II del 15 de octubre de 1696. El documento fue traído y ejecutado por este obispo el 24 de junio de 1699.

${ }^{30}$ Cayetano Bruno, Historia de la Iglesia en la Argentina, IV, Buenos Aires, 1969, 398.

31 Ibidem, 429.

${ }^{32}$ La visita del obispo puso al descubierto una serie de irregularidades que debían ser corregidas. Como las religiosas no aceptaron los términos y desafiaron la autoridad del ordinario, apelando a la justicia en diferentes instancias, el papeleo fue muy abundante. Cabe destacar que en esta oportunidad, como en otras que hemos estudiado, las monjas supieron formular respuestas. La visita y el curso de la misma han sido estudiados por Gabriela BRACCIO en «Un inaudito atrevimiento», Revista Andina, 32, (1988) 267-304 y en «Una gavilla indisoluble. Las teresas en Córdoba (siglo XVIII)». Historia de las mujeres en la Argentina. Colonia y siglo XIX, Buenos Aires, 2000, 153-171.

${ }^{33}$ En el Archivo del Arzobispado de Córdoba se encuentra la copia del «Testimonio de autos de visita del monasterio de Santa Teresa de Córdoba del Tucumán». Se trata de un expediente muy extenso de los años 1733 y 1734. Igualmente pueden leerse el «Testimonio de los autos sobre la visita del Con-
} 
Devoto de la pedagogía de la ejemplaridad, Zevallos, al igual que la mayoría de los prelados de la época, creía que las monjas, además de cumplir el rol de mediadoras ante Dios, debían cargar sobre sus hombros con el pesado yugo de la ejemplaridad. De allí la necesidad de una reforma que acercase a esas mujeres a los modelos de santidad admitidos en España o en Roma. La visita pastoral le permitió comprobar que los obispos que lo habían precedido en el cargo habían descuidado sus tareas, pero él, Caballero de la Orden de Santiago, doctor en sagrados cánones en Salamanca, inquisidor en Cartagena de Indias y en Ciudad de los Reyes, retomaría esos espacios de poder que le correspondían y pondría orden y haría cumplir la ley. El control del monasterio de las monjas carmelitas fue uno de esos espacios. Su extremado celo en el cumplimiento de la tarea, su ambición de controlarlo todo, de extender sus espacios de poder, su intento de cambiar las prácticas como medio para poner un pie en la clausura llegaron a su fin con el alejamiento de Zevallos de la diócesis de Córdoba en 1740 para asumir en Lima, donde había sido destinado por Benedicto XIV. De este modo se suspendió por un tiempo la ejecución de la reforma episcopal, que al fin, por sugerencia de las autoridades quedó incompleta.

En la segunda mitad del siglo el convento fue visitado en varias ocasiones: en 1748, recibieron la visita del obispo don Pedro Miguel de Argandoña Pavón y Zalazar; en 1766 la del obispo Manuel Abad Illana; diez años después, la de don José Domingo de Frías, en nombre del Obispo don Juan Manuel de Moscoso y Peralta; en 1782 la hace el Obispo Antonio de San Alberto; al año siguiente Mariano Calvo, provisor y vicario general y gobernador del obispado; en 1785, apenas un mes antes de abandonar la ciudad, José Antonio de San Alberto, volvió a visitar el monasterio; y en 1795 , realizó la que cierra el siglo y sirve de base para nuestro estudio, el obispo Ángel Mariano Moscoso. Obispos y gobiernos episcopales obligaron a las monjas a respetar la vida común y, sobre todo, se afanaron por controlar estrictamente los bienes y capitales del monasterio. Este último fue el logro principal de las reformas borbónicas.

La misma Teresa de Jesús había insistido en la importancia que revestían las visitas y, en consonancia con las disposiciones conciliares, el tratado teresiano remarcaba la necesidad de indagar sobre distintos aspectos del funcionamiento de la vida cotidiana, a través de los cuales se concretaban los votos profesados. La revisión del libro de gastos, las labores realizadas, del número de freilas admitidas aparece junto a las advertencias acerca de religiosas melancólicas, o de amistades particulares entre algunas de ellas. La indagación eclesiástica, según

\footnotetext{
vento de Carmelitas descalzas de la ciudad de Córdoba del Tucumán a continuación de los remitidos a su Majestad con duplicado y carta de 20 de agosto del año pasado de 34. Salta, 17 de abril de 1735» y el informe del Fiscal, fechado en Madrid el 25 de febrero de 1737. Legajo 57, Archivo General de Indias, T.1.
}

Hispania Sacra, LXII

126, julio-diciembre 2010, 697-721, ISSN: 0018-215-X 
Foucault, era entonces «mirada tanto sobre los bienes y las riquezas como sobre los corazones, los actos, las intenciones, etc. ${ }^{34}$

En su informe al rey, el obispo Moscoso declaró que había examinado detalladamente a la comunidad ${ }^{35}$ en diferentes aspectos y celebró «la decencia con que se mantiene el culto divino en su Iglesia, la estrictez con que observan la clausura, y la sujeción y entero arreglo a las Constituciones de su Regla dando a Dios infinitas gracias, al ver lo floreciente que se halla en este Monasterio la Disciplina regular». ${ }^{36}$ De hecho, según el visitador, a finales del siglo XVIII la comunidad se identificaba con un fuerte espíritu de unión, con pláticas renovadoras como la vida sacramental, a base de confesión semanal y comunión, generalmente quincenal; capítulo de culpas comunitario, una a dos veces por semana, practicando confesiones personales, acusaciones y denuncias. ${ }^{37}$

Una característica muy propia de la reforma teresiana fue el estricto orden jerárquico dentro del monasterio: la madre priora era quien llevaba la casa. Para Santa Teresa la obediencia era factor indispensable. De la designación de la priora dependían todos los oficios del convento, como maestra de novicias, torneras, sacristana, encargada del locutorio, etcétera. ${ }^{38}$ Se debía respetar a la priora pues «Dios la colocaba en ese lugar para obedecerla». Sin embargo la priora debía dar muestras de gran humildad y así: «la tabla de barrer se comience desde la madre priora para que en todo dé buen ejemplo». ${ }^{39}$

Podemos decir que la descalcez había dado nacimiento a un nuevo estilo de vida religiosa, orante y vivo ${ }^{40}$ que resurgía diariamente en el monasterio cordo-

\footnotetext{
34 Michel Foucault, La verdad y las formas jurídicas, Barcelona, 1995, citado por V. CoHEN IMACH, Decir verdad... 21-23.

${ }^{35}$ No se ha encontrado, si es que se realizó, el interrogatorio formalizado por el visitador a cada religiosa.

${ }^{36}$ AAC. Legajo 8. Tomo I, Monjas Teresas. Visita del Obispo Moscoso

37 «En los días domingo, y en los otros cualquier día, cuando hubiere necesidad, tratad de la guarda de vuestra Orden y de la salud de las alma, donde también con caridad sean corregidas las culpas, y excesos de las Hermanas, si en algunos fueren hallados.» TERESA DE Jesús, Obras Completas, Madrid, $1861,270-272$.

${ }^{38}$ Las clavarias, al igual que la Superiora eran elegidas por la comunidad en capítulo. Eran las encargadas de, mes a mes pedir cuentas a la portera y revisaban los libros de ingresos y egresos frente a la priora. Custodiaban, además, el arca de tres llaves, guardando dos de éstas. En dicho baúl se conservaban las escrituras y los depósitos económicos del monasterio.

${ }^{39}$ TeRESA DE Jesús, Libro de las Constituciones, Madrid, 1861, 269. De los tres votos y que tengan priora: Estatuimos primeramente y ordenamos, que tengáis una de vosotras por Priora para este oficio en concordia, y consulta de todas, o de la mayor o de la más acertada parte, a la cual cada una de las otra prometa obediencia, y después de haber prometido procure de la guardar, con obra y verdad, guardando asi mesmo, castidad y pobreza.

${ }^{40}$ Las que supieren rezar las Horas Canónicas, díganlas conforme a los estatutos y reglas de los Santos Padres, y a la costumbre aprobada por la Regla. Y las que no supieren dezir, digan por Maytines veinte y cinco vezes el Pater noster, excepto los días de domingo y fiestas solemnes de guardar, en las
} 
bés, según la visita del obispo Moscoso. De esa manera, se cumplían las expectativas de la sociedad cordobesa que podía descansar tranquila ya que en el convento se velaba por ella y se la custodiaba mediante la oración.

No obstante, el obispo amonestó la falta de silencio adecuado en la portería, si bien aclara de inmediato que no eran las religiosas las «desordenadas» sino las seglares presentes, ${ }^{41}$ que no se hallaban obligadas por la observancia y llevaban y traían las noticias del mundo secular, los presentitos escondidos y otras cosas que podían distraer a las religiosas por ello mandó que se aumentara allí la vigilancia y que no se permitieran en el torno conversaciones, sobre todo por parte de las criadas, de más de quince minutos ya que para dicho fin existía el locutorio. Igualmente exhortó a la priora a que mantuviera cuidadosamente separadas a las criadas de las religiosas y que las primeras realizaran sus labores en el patio que les correspondía. ${ }^{42}$

El monasterio, como «huerto cerrado» no se trataba de un ámbito de libre circulación, sino que exigía un riguroso control de ingreso y egreso de personas al mismo. Por ello, y como era esperable de todo prelado, señaló la necesidad de guardar apropiadamente la clausura de manera que, si algún peón debía entrar para realizar ciertos trabajos en el monasterio, no se encontrase con las religiosas.

Mandó, igualmente el obispo que, a fin de dar más libertad a las novicias, se les permitiera estar sin escuchas en el locutorio, ya que el noviciado era el tiem-

que ha de ser doblado el dicho número, conviene a saber cinquenta vezes el Pater noster, y por Laudes siete vezes el Pater noster, y en todas las otras horas del día siete vezes el Pater noster, salvo a Vísperas, que han de decir quinze. Ibidem 270.

${ }^{41}$ En la visita que realizara el obispo San Alberto encontró que dentro del monasterio las monjas tenían criadas, como era costumbre en la época, práctica que no era aceptada en el carmelo descalzo. Para no crear tensiones dispuso que no entraran nuevas y que las existentes se mantuvieran con la precaución que, a medida que fueran desapareciendo, no fueran renovadas. Igualmente mandó que fueran reducidas a siete las sirvientas, número que estimaba suficiente para atender bien el servicio del monasterio y que se prohibiera que actuaran de mandaderas, lo que llevaba mucha gente a la portería y restaba eficacia al trabajo que debían hacer, «para que de esta manera se evite el tráfico continuo de gentes y de parientes, que acuden a la portería por los negocios y recados de las que están dentro, y ellas tengan más tiempo para servir a Dios y al Monasterio». Ángel Clavero, Fray José Antonio... 71-73.

42 AAC. Legajo 8. Tomo I, Monjas Teresas. Visita del Obispo Moscoso. Se modernizó la grafía para una lectura más ágil: «Primeramente siendo el silencio recomendado por su Constitución, como tan propio, para que recogidos los espíritus puedan continuamente elevarse a la contemplación de las cosas espirituales, y divinas; y estado informado, que aunque en lo general lo guardan las Monjas, se quebranta frecuentemente con la Portería, con la conversación que en el torno tienen ellas, y las criadas, debía mandar y mandó que tanto la R. Madre Priora, como la Portera celen con toda vigilancia, se guarde en lo posible, silencia en esta Oficina;... Iten, aunque en lo interior del Convento Observan las Religiosas silencio en las horas prevenidas por su Constitución; es turbado por las seglaras, que considerándose no obligadas a su observancia lo quebrantan con ocasión de las de las agencias en que se ocupa».

Hispania Sacra, LXII

126, julio-diciembre 2010, 697-721, ISSN: 0018-215-X 
po de prueba en el que las que quisieran abrazar la vida monástica debían examinar su vocación con sinceridad. Aquellas que elegían ingresar en un convento carmelita lo hacían, con la certeza de que integraban una aristocracia espiritual. Eran mujeres austeras y orantes que dejaban precisamente los lujos del mundo para dedicarse a la vida contemplativa. La edad mínima de admisión eran los 17 años, una edad suficiente en aquella época para tomar una decisión de esta magnitud. El Carmelo fue muy cuidadoso en no admitir menores de edad. Por otro lado, no había una edad límite de ingreso.

El capellán y el obispo eran los encargados de examinar la voluntad de las novicias en el locutorio y realizar las preguntas de rigor. Era necesaria una vocación a la vida religiosa, una inclinación que diera muestras de gusto y deseo de llevar el peso de una vida de mucha disciplina y abnegación. ${ }^{43}$ Sabemos, sin embargo, que en los monasterios femeninos del Antiguo Régimen, muchas veces la decisión la tomaban los padres, indistintamente uno de otro, quienes se hacían obedecer dócilmente por sus hijas. A pesar de las disposiciones eclesiásticas, no siempre las novicias actuaban con «libre y espontánea voluntad» sino que, en muchas ocasiones, era la de los familiares la que se imponía, ya que eran estos quienes llevaban a las jóvenes al monasterio. No obstante la posición oficial de la iglesia contra las profesiones forzadas era notoria la dificultad que encontraban los conventos para erradicar -si es que se lo proponían- las estrategias familiares de casar sólo a algunas de las hijas y buscar la religión para las otras. 44

Dudas sobre la legitimidad de una hija, miedo por la desintegración de la fortuna familiar, así como la ausencia de belleza o de inteligencia podían ser motivos suficientes para «encerrar» a una joven en el mundo conventual.

Tres aspectos más son tratados por el obispo Moscoso en su visita. Uno, relacionado con el oficio de Portera, y los otros dos, atendiendo sendos pedidos de la comunidad sobre horarios y comidas. ${ }^{45}$ Con respecto al primero, hay que

\footnotetext{
${ }^{43}$ El decreto De regularibus et monialibus en la sesión XXV del concilio de Trento, restableció la observancia de la vida monástica, de la comunidad de los bienes y de la clausura de las monjas. Las vocaciones forzadas eran consideradas como una causa mayor de desórdenes en las comunidades y varias medidas debían atajarlas: fijar una edad mínima para tomar el hábito, y un año de prueba antes de profesar. Antes de tomar el hábito y antes de pronunciar los votos, la vocación de la postulante debía ser examinada por el ordinario. I. Poutrin, La mujeres en el siglo... 524.

44 Mary Laven, Monache. Vivere in convento nell'etá della Controriforma. Roma, 2004,116. G. Nieva OCAMPO y A. M. GonZÁlez FASANI, «Relicario de vírgenes. Familia monástica en el convento de Santa Catalina de Córdoba del Tucumán (1730-1750)», C. FolQUER (ed.), La Orden dominicana en Argentina: actores y prácticas. Desde la Colonia al siglo XX, San Miguel de Tucumán, 2008, 23-54.

${ }^{45}$ Hay un cuarto aspecto que se relaciona con las actividades desarrolladas por la Cofradía del Carmen, tema que ha sido estudiado específicamente por Ana María Martínez de Sánchez en La cofradía del Carmen en la Iglesia de Santa Teresa de Córdoba, ya citado.
} 
tener en cuenta que el oficio de portera, por su relación con las personas laicas, exigía suma confianza. La portera, también llamada receptora o provisora, se encargaba de la elaboración de una lista de todo lo necesario en el convento. Escribía en libros, destinados para ello, el gasto y el recibo de la casa, tal como había mandado su Ilustrísima fray Antonio de San Alberto en el año 1782.46 Su forma de comunicación con el exterior era siempre el torno, que impedía el rompimiento de la clausura. La obligación de la portera era dar cuentas directas a la priora de todo lo que sucedía y pasaba por el torno. No llamaba a ninguna hermana al torno sin avisarle antes. Era ella quien otorgaba o negaba el permiso de visita. También dirigía a la priora toda carta o aviso que ingresara al convento por el torno.

Era costumbre en el monasterio convidar con mates ${ }^{47}$ a los sacerdotes que iban a decir misa y a las demás visitas y era la Portera la que corría con los gastos. El obispo mandó que de allí en más no los costeara ella, sino la comunidad sacándolo del gasto común.

La tónica de la vida carmelita era: austeridad y penitencia expresada por la rigurosa alimentación -pues se prohibía la carne y el exceso de dulces- y los constates ayunos, ${ }^{48}$ además de los horarios cuadriculados que no permitían tiempos de ocio: «Lo primero que hemos luego de procurar, quitar de nosotras el amor de este cuerpo [...] y determinaos, mis hijas, que venís a morir por Cristo y no regalaros por Cristo». ${ }^{49}$ Ahora bien, el obispo Moscoso comenta que «se había introducido la costumbre de que en la cuaresma y tiempo de ayuno solo se dé a las Monjas por colación una tortita de tres onzas, lo cual agrega-

46 «Que en la Arca de depósitos de Capitales haya un libro, el cual está dividido en dos partes, y en la primera se pongan con toda claridad y distinción las partidas que entran [...] y en la segunda, las salidas [...]». Citado por A. Clavero, Fray José Antonio... 66.

${ }^{47}$ Esta referencia al mate pone de manifiesto que esa bebida era un sustento importante no sólo en los monasterios. Las bebidas no alcohólicas más difundidas eran el chocolate, el café y por supuesto, el mate, que se consumía en grandes cantidades y por todas las clases sociales. Hasta en unas instrucciones sobre la manera de hacer los ejercicios espirituales en Montevideo figura una cláusula que prescribe: «de las tres y media a las cuatro en sus cuartos a tomar mate». José María MARILUZ URQUIJO, El Virreinato del Río de la Plata en la época del marqués de Avilés (1799-1801), Buenos Aires, 1964, 359.

48 Santa Teresa en el Libro de las Constituciones, dice: «Ayunareis todos los días, excepto los Domingos, desde la misma fiesta de la Encarnación de la Cruz, hasta el día de la Resurrección del Señor, si enfermedad o flaqueza, o otra justa causa no os persuadiere a quebrar el ayuno, porque la necesidad no tiene ley. No comeréis carne si no fuere por remedio de enfermedad o flaqueza. [...] comeréis caldo con las verduras[...]».

${ }^{49}$ Santa Teresa de Jesús, Camino de perfección, capítulo 10, 5. Trata cómo no basta desasirse de lo dicho, si no nos desasimos de nosotras mismas, y cómo están juntas esta virtud y la humildad:5. Ahora, pues, lo primero que hemos de procurar es quitar de nosotras el amor de este cuerpo... Determinaos, hermanas, que venís a morir por Cristo, y no a regalaros por Cristo. Sobre los rigores infrigidos al cuerpo puede consultarse Jacques GÉLIS, «El cuerpo, la Iglesia y lo sagrado», en Alain CoRBIN et. al., Historia del Cuerpo, Madrid, 2005, 55-56.

Hispania Sacra, LXII

126, julio-diciembre 2010, 697-721, ISSN: 0018-215-X 
do a la continua abstinencia de la carne causa bastante debilidad en algunas». Por ello mandó que no siendo opuesto al ayuno un guiso moderado, se les diese como colación y que, aunque algunas no lo tomasen por mortificación, permaneciera la comunidad junta en el Refectorio. ${ }^{50}$

La oración no era el rezo sino la búsqueda de la amistad con Dios. Profesionales de esta actividad, las carmelitas tenían como obligación primordial, rezar dos veces al día. En el verano, de las cinco a las seis de la mañana, y en el invierno, de las seis a las siete. Por la noche, una hora antes de los maitines, hacia las ocho de la noche. A la oración le seguía la lectura del Oficio Divino, rezando los Salmos, a dos coros. En el auto producto de la visita realizada por el obispo Moscoso se comenta el exacto cumplimiento de todos los actos sagrados. Por ello concedió que se ajustaran los horarios de acuerdo a la conveniencia de las religiosas.

\section{PATRIMONIO, HABER Y GASTOS A FINALES DEL SIGLO XVIII}

Para conjurar el grave déficit fiscal que aquejaba a la Corona Española en las últimas décadas del siglo, como consecuencia, principalmente, de las guerras que sostenía con Inglaterra y con Francia, los monarcas trazaron un plan para el corto plazo consistente en obtener recursos genuinos para la amortización de los vales reales en circulación o, dicho de otro modo, para paliar la crisis de la Hacienda. A largo plazo, el objetivo era la desamortización de la propiedad vinculada en general y de la propiedad eclesiástica en particular, ${ }^{51}$ de manera que, la inspección del capital de los monasterios y conventos se había convertido en una de las obligaciones primordiales de los obispos desde la publicación del Tomo Regio.

Ante las crecientes necesidades económicas de la monarquía durante el reinado de Carlos IV, los obispos son enviados para cumplir funciones relacionadas con la recaudación de bienes y sus informes abundaban en detalles y minucias en este rubro. ${ }^{52}$ El obispo Ángel Mariano Moscoso mandó el suyo al rey en

\footnotetext{
50 Otras formas de penitencia comunitaria se aplicaban en el refectorio: dejar comida en el plato, comer en el suelo, besar los pies a las religiosas mientras comían, recibir bofetadas y ponerse en cruz en medio del comedor. Para comer en el suelo se les colocaba una venda en los ojos, mordaza, saco y soga. En general, estas mortificaciones las decidía la priora. Para un análisis de la experiencia alimentaria en el seno de la Orden véase María Merce Gras i CASANOVAS, «Cuerpo y alma en el Carmelo Descalzo femenino: una aproximación a la alimentación conventual en la Cataluña moderna», Studia Historia, 14 (1996) 207-222.

51 Abelardo LeVAGgi, «La desamortización eclesiástica en el Virreinato del Río de la Plata», Revista de Historia de América, 102 (1986) 7.

52 AAC, Legajo 14. Por Real Cédula del 6 de marzo de 1790 Carlos IV ordenó el cobro de un subsidio a la Iglesia americana por el monto de 2 millones de ducados de plata. El obispo Moscoso pagó
} 
1801. En él se le informó que la dote que se pagaba para entrar al monasterio de San José ascendía a 2000 pesos, es decir quinientos pesos menos que la que se solicitaba en el de dominicas, que había aumentado a 2500 pesos. ${ }^{53}$ Sobre cómo manejaba el monasterio sus dineros y rentas explicaba al rey que:

Por estatuto y por máxima acreditada de la experiencia nunca se echa mano de los principales para sustento de la comunidad, y debiendo esto salir de sus réditos, lo arraigan sobre fincas de particulares que los toman con el interés de un 5\% al año o se construyen edificios rentables en suelos del Monasterio. El estado en que actualmente se encuentran estas rentas pone muy distante de que sea simoniaco el percibo de las dotes..$^{54}$

A fin de avalar la acción de sus predecesores, preocupados por controlar las rentas y la administración de los bienes conventuales, dice que, literalmente, lo salvaron de una ruina segura debido al «desarreglado manejo con que se habían administrado en lo antiguo». ${ }^{55}$ En efecto, ya en 1729 el obispo Juan de Sarricolea y Olea, que había ensalzado la disciplina que encontró en los monasterios cordobeses, ordenó que se tuviera mayor cuidado en la tenencia de los libros de cuentas y nombró nuevos síndicos. ${ }^{56}$ Por otra parte las ordenanzas que había dejado San Alberto en 1782 para que se confeccionasen libros de censos, profesiones, elecciones, etc., permitieron a las monjas controlar mejor sus bienes. ${ }^{57}$

$\mathrm{Y}$ es que la estrategia inversionista de las instituciones religiosas buscaba obtener una renta que les permitiera sustentarse sin consumir el capital que poseían. Por ello, las inversiones que realizaban se orientaban al largo plazo y a mecanismos que proporcionaran una renta suficiente para mantenerse sin

en cuatro anualidades el monto que le correspondía. Sobre el tema ver Elida TEDESCO, «Iglesia y crédito en Córdoba. Los cambios a fines del periodo borbónico a las primeras décadas independientes», en Gardenia Vidal y Pablo Vagliente (comp.), Por la señal de la cruz. Estudios sobre la Iglesia Catolica y sociedad en Córdoba. S. XVII-XX, Córdoba, 2002, 55-92.

53 «Informe del obispo Moscoso al rey sobre su obispado», La Revista de Buenos Aires. Historia americana, literaria y derecho, XXV, (1871) 65.

${ }^{54}$ Idem.

${ }^{55}$ El texto dice «que hasta el año 1756 llevaba perdido el Monasterio de Dominicas 2300 pesos y el de Carmelitas a proporción de sus haberes, llegó tiempo en que las necesidades tocaron sus extremos y se vio este último en la precisión de desnudar sus imágenes para vestir su comunidad. Consistían estas [las causas de la crisis] en la mala versación de los Síndicos o Ecónomos que siendo por lo común gente fallida aspiraban a este empleo para salvar sus quiebras a expensas de estos intereses». Ibidem, p. 65 bis.

${ }^{56}$ Entre 1726 y 1730 ocupó la diócesis el doctor don Juan de Sarricolea y Olea, undécimo obispo del Tucumán. Dijo de los monasterios de monjas « [...] a cuya clausura vienen de todas las ciudades de estas tres gobernaciones [...] Las religiones proceden todas con buena regularidad y edificación común mayormente en los conventos grandes y capitulares de esta ciudad, donde florece más la observancia». Cayetano BRUNo, Historia de... 429.

57 «En tiempos de mi predecesor el R. Obispo don José Antonio de San Alberto empezó el sistema de administración en que se tomaron las medidas convenientes para atajar este daño». Informe del Obispo Moscoso... 65 bis.

Hispania Sacra, LXII

126, julio-diciembre 2010, 697-721, ISSN: 0018-215-X 
arriesgar su capital. En otras palabras, más que buscar una mejor rentabilidad apuntaban a una mayor seguridad. Con ese fin adquirían inmuebles y otorgaban préstamos de dinero (censos consignativos y depósitos). Las casas se alquilaban, como ocurría con otros conventos femeninos en América y en la Península, ${ }^{58}$ o se entregaban a censo enfitéutico. ${ }^{59}$ Los bienes hipotecarios, gravados con censos a favor de las carmelitas, eran variados, pero se concentraron sobre todo en casas dentro de la traza urbana. También podían hipotecarse capellanías. Al funcionar como unidad crediticia, debido a los numerosos censos consignativos otorgados a particulares de la sociedad cordobesa, muchas veces se hicieron con propiedades muebles cuando sus deudores no pudieron cumplir con sus obligaciones.

Tómese como ejemplo lo sucedido en 1741, cuando la madre priora y las cuatro clavarias, reunidas con el escribano público del cabildo, dijeron que: «Por fallecimiento del doctor don Francisco Vilches y Montoya quedaron en la traza de esta ciudad unas casas que actualmente está poseyendo este dicho monasterio, las cuales tiene pedidas el sargento mayor don Antonio Zevallos y A1monaci se le vendan, y habiendo ocurrido ante [la autoridad pertinente] para que el dicho monasterio pudiere vender las dichas casas al dicho sargento mayor...». ${ }^{60}$ La transacción se realizó en 1400 pesos; 1000 pesos por el principal, que el monasterio tenía en esas casas, y los 400 pesos restantes por los corridos que se tenían atrasados. Las monjas exigían recibir de contado en plata sellada 900 pesos y los 500 restantes a crédito sobre las casas, estancia y los demás bienes que poseyera el comprador. El monasterio recibió el dinero que fue guardado en la caja del depósito. ${ }^{61}$ Para poder solventar sus gastos, las monjas necesitaban el metálico. Por ello procuraban vender las casas que recibían.

\footnotetext{
58 Cfr. Carmen SorIANO TRIGUERO, «La propiedad inmobiliaria de los conventos femeninos madrileños en el siglo XVIII «Cuadernos de Historia Moderna, 24 (2000), 11-31.

${ }^{59} \mathrm{El}$ censo enfitéutico, permitía transferir un bien raíz, generalmente a perpetuidad o por larga duración, bajo la obligación de pagar, por parte del que la recibía, una renta anual. El censo consignativo era un préstamo a muy largo plazo. En la operación, el acreedor entregaba una suma de dinero al deudor; éste gravaba un bien raíz y no determinaba una fecha para la devolución, la cual quedaba abierta y a merced del deudor. El deudor, por su parte, se comprometía a pagar los réditos mientras no redimiese el principal. Jurídicamente el censo era una venta y no un préstamo. El acreedor compraba los derechos a percibir una renta anual (réditos) y a cambio entregaba al deudor una suma de dinero (principal). De este modo la redacción del contrato seguía el modelo de una escritura de compraventa y no de préstamo. Gisela Von Wobeser, El crédito eclesiástico en Nueva España, México, 1994, 51-61.

${ }^{60}$ AAC, Expediente sobre la licencia dada a las madres monjas de Santa Teresa de Jesús para la venta de las casas, Legajo 8, Tomo 1, Monjas Teresas.

${ }^{61}$ Otro caso de los numerosos que podemos citar es el de Francisco de Peralta, nacido en Santiago de Chile, mercader, gravó su propiedad con un censo de 500 pesos, sus sucesores cedieron la propiedad al monasterio por el censo y en trueque, por parte de la que dejó el maestre de campo don Fadrique Álvarez de Toledo, tasada en 500 pesos, el 7 de junio de 1722 .
} 
El obispo Moscoso finalizó su visita pidiéndole al síndico procurador, licenciado José Manuel Martínez, un minucioso estado de cuentas del monasterio. Martínez contestó por escrito que, «además de los principales que tan anotados hay en la capital de Buenos Aires sobre treinta a cuarenta mil pesos que no lo sé con individualidad pero vienen de allí de quinientos a seiscientos pesos anuales de estos principales pero dice aquel síndico que son muy trabajosos su cobro». ${ }^{62}$ Junto a este dinero cobrado en Buenos Aires, el informe comunica que las casas y tiendas que el monasterio tenía en alquiler pagaban al año 1200 pesos «sin incluir a las que actualmente están trabajando».

Los registros, asentados cuidadosamente en los libros del monasterio, en 1795 muestran que los pagos del principal se hacían en plata y en frutos de la tierra y que los primeros superaban notablemente a los segundos. Los principales pagados en plata ascendían a 21.900 pesos y los pagados con productos, a 9.120 pesos. También se agregaba en la nómina los principales que están sin redituar, 11.433 pesos, con 3 reales, que daba un total de 42.453 pesos, con 3 reales. ${ }^{63}$

Si bien la economía natural y la economía monetaria coexistieron a lo largo del siglo XVIII, a finales del mismo, la segunda superará a la primera ${ }^{64} \mathrm{El} \mathrm{co-}$ mercio interno se había agilizado con el cambio de la política económica española en Indias y también con la reactivación de los intercambios con Buenos Aires. Además del intenso comercio a larga distancia, se produjo un comercio de menor escala con las provincias vecinas y las poblaciones de la propia Intendencia, en el que participaron muchas personas. El movimiento de bienes, comerciantes y fiadores fue muy importante. ${ }^{65}$

El licenciado Martínez aclara: «no hay actualmente en la caja de depósito ni un medio real de principal, y de réditos hay la cantidad que se da existente en la cuenta de la actual priora, a que me remito».66

\footnotetext{
${ }^{62}$ AAC, Señor Provisor y Gobernador del Obispado, Legajo 8, T. I, Monjas Teresas.

${ }^{63}$ Consúltese el anexo final.

${ }^{64}$ Ceferino Garzón Maceda, Economía del Tucumán. Economía natural y economía monetaria. Siglos XVI-XVII-XVIII, Córdoba, 1968, 4.

${ }^{65}$ Lilians Betty Romero CABRERA, La «Casa de los Allende» y la clase dirigente: 1750-1810, Córdoba, 1993, 158-159. Ana Inés PunTA, Córdoba Borbónica. Persistencias coloniales en tiempo de reformas (1750-1800), Córdoba, 1997.

${ }^{66}$ AAC, Legajo 59, Tomo I, Historia del Monasterio de Santa Teresa, Principales que están corrientes..., Iten a los 21.900 pesos de principales corrientes y que pagan en plata corrientemente se debe agregar la escritura del finado Cabral (que actualmente está en autos) de cantidad de 1600 pesos y son dichos principales 23.500 pesos y sus réditos anuales son 1175 pesos.

Iten se advierte que el cuarto en que yo vivo, y la esquina y trastienda contigua a él, se trabajaron también con parte de la dote de una religiosa y que actualmente y desde ahora nueve años no reditúan cosa alguna. El cuarto en que yo vivo porque me lo tienen prestado con respecto a que esté más cerca del convento por lo que ocurre a cada paso; si bien yo no me desentiendo de hacerlos los socorros que
}

Hispania Sacra, LXII

126, julio-diciembre 2010, 697-721, ISSN: 0018-215-X 
El informe de Moscoso al rey declara que los principales que tiene el monasterio de Carmelitas ascienden a cincuenta y tres mil trescientos ochenta con el rédito de dos mil quinientos nueve pesos, «que así estos principales con sus intereses, tienen todas las seguridades de que son susceptibles por su naturaleza, que manejados por manos fieles, activas e interesadas en su conservación y aumento, las comunidades se ven mucho mejor asistidas y tienen una fundada esperanza de que esta preciosa administración cubrirá las quiebras de la antigua».67

Gracias a que el número de monjas se mantuvo siempre dentro de lo que las constituciones mandaban, al pago de las dotes, a que los bienes aportados en la fundación eran sustanciosos, a una buena aunque tardía administración, y, sobre todo a que las rentas eran pagadas con puntualidad y en metálico, podemos concluir que las religiosas no padecían necesidades económicas dentro de su comunidad.

\section{CONSIDERACIONES FINALES}

El monasterio de San José de Carmelitas Descalzas fue fundado el 7 de mayo de 1628 a instancias de don Juan de Tejeda Miraval, vecino feudatario, que donó su casa y propiedades para ver cumplida la promesa que le hiciera varios años atrás a la santa.

Se han analizado las profesiones y las finanzas de las últimas dos décadas del siglo XVIII, específicamente los años que van de 1780 a 1806. Pudimos visualizar una ciudad cuya población seguía en ascenso y que tenía características heterogéneas ya que estaba compuesta por españoles, criollos, estudiantes universitarios y colegiales del Seminario y Monserrat, indios, negros y mestizos.

El convento será uno de los espacios de prestigio donde las hijas de las familias con importantes recursos económicos no sólo de la ciudad de Córdoba sino también de la jurisdicción del Tucumán e incluso de Buenos Aires, ingresarán para vivir «apartadas del mundo», si bien no de algunas de sus categorías, ya que las jerarquías internas, la diferenciación entre religiosas, seglares y servidumbre, moldearon las relaciones de las involucradas en el funcionamiento del monasterio. «Muertas al mundo» no significaba solas y olvidadas ya que las religiosas seguían relacionándose con el exterior, manteniendo los vínculos entre ellas y los pobladores de las ciudades, incluyendo a sus familias y las autoridades coloniales.

puedo y la esquino porque la tienen prestada al mulato Elías que en ella trabajó todas las tallas del retablo, el sagrario, y otras obras sin interés y está pronto a trabajar cuanto se le pido para el convento.

${ }^{67}$ Informe del obispo Moscoso... 65. 
Se ha visto como interactuaban con su medio a través de prácticas jurídicas o financieras, como litigios, compra y venta de inmuebles y préstamos de dinero a las familias que lo solicitaran.

En el ocaso de la Edad Moderna, frente a situaciones políticas, económicas y sociales cambiantes, permanece aunque con la capacidad de amoldarse a las necesidades y reformas de su tiempo, un proyecto puesto en marcha en el siglo XVI por una mujer fuerte y tesonera y por un rey que se identificó con la reforma hasta hacerla parte de su modelo político. El de San José de Córdoba, era, a finales del siglo XVIII, un monasterio floreciente, donde se practicaba la disciplina regular, la vida en común y, según el último visitador del siglo, al que había que cuidar para que no decreciera.

\section{ANEXOS}

\section{Principales, cuyos réditos se pagan en plata corriente y no deben nada atrasado}

\begin{tabular}{|l|r|r|}
\hline & Principal & Réditos anuales \\
\hline $\begin{array}{l}\text { Primeramente doña Mercedes Roldán por escritura de 30 } \\
\text { de enero de } 1787 \text { de mancomún con su finado don Felipe } \\
\text { Haedo tiene a censo el principal de 2000 pesos de la dote } \\
\text { de su hija. }\end{array}$ & 2000 & 100 \\
\hline $\begin{array}{l}\text { Don Javier de la Torre por obligación de 31 de enero de } \\
1783 \text {, tiene a réditos la cantidad de un mil pesos }\end{array}$ & 1000 & 50 \\
\hline $\begin{array}{l}\text { Don Felipe Gonzalez por su vale de 20 de febrero de } \\
1794 \text { y con licencia expresa de SSI tiene a réditos ocho- } \\
\text { cientos pesos }\end{array}$ & 800 & 40 \\
\hline $\begin{array}{l}\text { El presbítero don Juan Bautista Ortiz por escritura de 20 } \\
\text { de marzo de 1783 tiene a censo trescientos pesos }\end{array}$ & 300 & 15 \\
\hline $\begin{array}{l}\text { Doña Jacinta Gutiérrez por escritura 75 de 4 de marzo de } \\
1790, \text { tiene a censo 1500 pesos }\end{array}$ & 1500 & $144 \mathrm{r}$ \\
\hline $\begin{array}{l}\text { Don Tiburcio Olmos por su vale de 2 de abril de 1794 } \\
\text { tiene a réditos 350 pesos }\end{array}$ & 350 & 25 \\
\hline $\begin{array}{l}\text { Don Solano Arce por escritura de 5 de mayo de 1792 } \\
\text { tiene a censo quinientos pesos }\end{array}$ & 500 & 25 \\
\hline $\begin{array}{l}\text { Don Juan Sotomayor por su vale de 10 de Mayo d 1792 } \\
\text { tiene a réditos 500 pesos }\end{array}$ & 500 & 40 \\
\hline $\begin{array}{l}\text { Doña Petrona López por escritura de 21 de mayo de 1783 } \\
\text { tiene a censo 800 pesos }\end{array}$ & 800 & \\
\hline
\end{tabular}

Hispania Sacra, LXII

126, julio-diciembre 2010, 697-721, ISSN: 0018-215-X 


\begin{tabular}{|c|c|c|}
\hline & Principal & Réditos anuales \\
\hline $\begin{array}{l}\text { Doña Catalina Tejeda está hecha cargo de mil pesos de la } \\
\text { dote de su hija desde } 9 \text { de junio de } 94 \text { y ha pagado los ré- } \\
\text { ditos cumplido el primer año. }\end{array}$ & 1000 & 50 \\
\hline $\begin{array}{l}\text { Don Miguel Argüello por escritura de } 23 \text { de junio de } \\
1792 \text { tiene a censo quinientos pesos }\end{array}$ & 500 & 25 \\
\hline $\begin{array}{l}\text { Don Javier Medina por su vale de } 26 \text { de junio de } 1794 \text { y } \\
\text { con licencia de SSI tiene a rédito } 250 \text { pesos }\end{array}$ & 250 & $124 r$ \\
\hline $\begin{array}{l}\text { Don Ambrosio Funes por su vale de } 29 \text { de junio de } 1790 \text {, } \\
\text { tiene a réditos } 400 \text { pesos }\end{array}$ & 400 & 20 \\
\hline $\begin{array}{l}\text { Mis hermanos don Olegario y don Dalmacio por obliga- } \\
\text { ción firmada por mí como fiador, tienen a réditos mil y } \\
\text { seiscientos pesos de principal }\end{array}$ & 1600 & 80 \\
\hline $\begin{array}{l}\text { Doña Teresa Suárez por escritura de } 28 \text { de agosto de } \\
1789 \text { tiene } 200 \text { pesos a censo }\end{array}$ & 200 & 10 \\
\hline $\begin{array}{l}\text { Don Manuel Rodríguez por escritura de } 13 \text { de agosto de } \\
1788 \text { tiene a censo } 2 \text { mil pesos dote de su hermana }\end{array}$ & 2000 & 10 \\
\hline $\begin{array}{l}\text { Don Francisco Clemente Olmos por Escritura de } 1 \text { de } \\
\text { [...] de } 1790 \text { tiene mil pesos a censo }\end{array}$ & 1000 & 50 \\
\hline $\begin{array}{l}\text { Don Alejando Osán por su vale de } 28 \text { de septiembre de } \\
93 \text {, debe doscientos pesos a interés }\end{array}$ & 200 & 10 \\
\hline $\begin{array}{l}\text { Doña Clara Echenique tiñe a réditos mil pesos. } 30 \text { de oc- } \\
\text { tubre. }\end{array}$ & 1000 & 50 \\
\hline $\begin{array}{l}\text { Doña Damiana Figueroa reconoce mil pesos a censo de } \\
\text { la escritura de su finado esposo de } 7 \text { de octubre de } 773\end{array}$ & 1000 & 50 \\
\hline $\begin{array}{l}\text { El Dr. Don Vicente Ferreira por escritura de } 18 \text { de octu- } \\
\text { bre de } 793 \text { tiene a censo } 600 \text { pesos }\end{array}$ & 600 & 30 \\
\hline $\begin{array}{l}\text { Don Olegario Martínez mi hermano por su vale de } 26 \text { de } \\
\text { mayo y licencia de SSI tiene a réditos } 500 \text { pesos }\end{array}$ & 500 & 25 \\
\hline $\begin{array}{l}\text { En la quinta dicha del Alemán están afincados mil y cien } \\
\text { pesos y por ellos mientras se extiende la escritura, firmé } \\
\text { yo fianza en } 17 \text { de noviembre de } 1794\end{array}$ & 1100 & 55 \\
\hline $\begin{array}{l}\text { En las casas de enfrente del monasterio se gastaron de prin- } \\
\text { cipal } 1600 \text { pesos y producen corrientemente a más del } 5 \%\end{array}$ & 1600 & 80 \\
\hline $\begin{array}{l}\text { La hacienda de Añáscate se ha arrendado recién a don } \\
\text { Manuel Rodríguez por } 60 \text { pesos en plata que corresponde } \\
\text { al principal de } 1200 \text { pesos }\end{array}$ & 1200 & 60 \\
\hline & 21900 & 1095 \\
\hline \multirow[t]{2}{*}{$\begin{array}{l}\text { El finado Cabral y por su muerte su Viuda y don Antonio } \\
\text { Cobos }\end{array}$} & 1600 & 80 \\
\hline & 23500 & 1175 \\
\hline
\end{tabular}




\section{Principales cuyos réditos se pagan en efectivo y están también corrientes o que si deben algo atrasado, es poco}

\begin{tabular}{|l|r|r|}
\hline & Principales & Réditos \\
\hline $\begin{array}{l}\text { Sobre la estancia de San Marcos a cargo del Sr. Provisor } \\
\text { como apoderado del deán de Santa Cruz a quien pertene- } \\
\text { ce cargan 500 pesos }\end{array}$ & 500 & 25 \\
\hline $\begin{array}{l}\text { El Convento de la Merced de esta Ciudad por escritura } \\
\text { del 1 de enero de 1792 hizo reconocimiento de 500 pesos }\end{array}$ & 500 & 25 \\
\hline $\begin{array}{l}\text { Doña Jacinta Alvarez por la dote de su hija la madre Ma- } \\
\text { ría Alberta reconoce 2 mil y paga en efectos }\end{array}$ & 2000 & 100 \\
\hline $\begin{array}{l}\text { Sobre las casa del finado doctor Sarmiento fincan } 600 \\
\text { pesos de principal, cuyos réditos se pagan en frutos }\end{array}$ & 600 & 30 \\
\hline La finada doña Teresa Tobolina 100 pesos de principal & 100 & 5 \\
\hline Sobre la estancia del Totoral 900 pesos y paga en efectos & 900 & 45 \\
\hline Sobre la estancia de la Tapia 600 pesos & 600 & 30 \\
\hline $\begin{array}{l}\text { Sobre la estancia del Pilar del Río Segundo están 320 pe- } \\
\text { sos }\end{array}$ & 320 & 16 \\
\hline Sobre la misma estancia de la parte del Norte 300 pesos & 300 & 15 \\
\hline Sobre la estancia de Sigiman 1200 pesos & 1200 & 60 \\
\hline Don Francisco Zeballos sobre sus casas 1200 pesos & 1200 & 60 \\
\hline Sobre la estancia de Copacabana Doña Manuela Olmos & 200 & 10 \\
\hline El maestro Olmos 700 pesos de la dote de su sobrina & 700 & 35 \\
\hline & 9129 & 456 \\
\hline
\end{tabular}

\section{Otros principales que están casi perdidos y algunos litigiosos y otros que deben muchos réditos y pagan con dificultad}

\begin{tabular}{|l|l|l|}
\hline $\begin{array}{l}\text { Doña Polonia Ascasubi tiene escritura de mancomún con } \\
\text { su finado esposo Arredondo de 500 pesos de principal y } \\
\text { desde que murió este no paga nada y se llama a dote. }\end{array}$ & 500 & \\
\hline $\begin{array}{l}\text { La casa de Urtubey 1233 pesos 3 reales. Deben muchos } \\
\text { réditos y está en pleito que actualmente se agita }\end{array}$ & 1233 3r & \\
\hline $\begin{array}{l}\text { Doña Rosa Tablado (suegra de Don Francisco Signo) re- } \\
\text { conoce 500 pesos y otros 500 pesos su hermana Juana } \\
\text { Teresa de don Pedro Arismendi } 1500 \text { de otra dote. Hace } \\
\text { muchos años que no pagan y parece que no hay ya otro } \\
\text { remedio que vender las fincas, que me aseguran están } \\
\text { restituidas. Deben muchos réditos atrasados. Doña Rosa } \\
\text { tal cual Tiene } 1500 \text { pesos. Están cuasi perdidos deben } \\
\text { muchos caídos y no hay otro remedio que venderla antes }\end{array}$ & & \\
\hline
\end{tabular}




\begin{tabular}{|c|c|c|}
\hline $\begin{array}{l}\text { que se acabe de perder. Sobre esto he tratado ya con SSI } \\
\text { paga de cuando en cuando alguna cosa; pero doña Teresa } \\
\text { se ha echado con la carga. Ya de esto he tratado con SSI }\end{array}$ & 1000 & \\
\hline $\begin{array}{l}\text { Doña Isabel Salas } 200 \text { pesos debe Réditos atrasados y es } \\
\text { insufrible Cuando se trata de cobrarle. La he Demandado } \\
\text { mil veces, pero sin fruto alguno }\end{array}$ & 200 & \\
\hline $\begin{array}{l}\text { La casa del finado don Martín Doncel tiene mil pesos, } \\
\text { debe algunos réditos por su muerte quedaron sus hijos en } \\
\text { notoria pobreza. No se ha hallado quien compre la casa y } \\
\text { teniendo una religiosa hermana se les tolera }\end{array}$ & 1000 & \\
\hline $\begin{array}{l}\text { La casa del finado don Manuel Jacinto Nieto tiene } 400 \\
\text { pesos de principal. Debe bastantes réditos. El albacea, } \\
\text { doctor don Juan Luis Aguirre, reconvenido por mí mu- } \\
\text { chas veces, dice que hará por venderla y pagar }\end{array}$ & 400 & \\
\hline La chacra de los Cabrera en la Rioja & 1500 & \\
\hline $\begin{array}{l}\text { La testamentaría de don Simón Avechucho en Santa Fe } \\
\text { debe dos mil pesos de la dote de una religiosa; y la }\end{array}$ & 3500 & \\
\hline $\begin{array}{l}\text { Joaquín Olivera } 100 \text { pesos sólo ha pagado un año desde } \\
1789 \text { con que hizo la escritura }\end{array}$ & 100 & \\
\hline $\begin{array}{l}\text { Don Juan López por escritura de } 20 \text { de Junio de } 1783 \text { de- } \\
\text { bía } 2 \text { mil sobre los Molinos del paso que posteriormente } \\
\text { trasladó al Molino futuro o por hacer de la acequia por } \\
\text { escritura de } 23 \text { de octubre de } 93 \text {. Debe réditos atrasados, } \\
\text { y en la escritura nueva no se expresaron las condiciones } \\
\text { con que el Monasterio accedió a este traspaso y constan a } \\
\text { SSI }\end{array}$ & 2000 & \\
\hline $\begin{array}{l}\text { El mismo don Juan López sobre la casa en que vive y te- } \\
\text { nía sobre sí mil pesos de principal; los reconoce con con- } \\
\text { dición de pagar sus réditos en harina por escritura que } \\
\text { hizo en } 12 \text { de octubre de } 1784 \text {. También de esta cuenta } \\
\text { debe bastantes réditos }\end{array}$ & & \\
\hline Suma & 11433 3r. & \\
\hline
\end{tabular}

Licenciado José Manuel Martínez. Síndico Procurador.

Córdoba y julio 23 de 1795. 